\title{
Blessing for the Bleeder: Bevacizumab in Hereditary Hemorrhagic Telangiectasia
}

\author{
Narendranath Epperla, MD and William Hocking, MD, FACP
}

\begin{abstract}
Hereditary hemorrhagic telangiectasia $(\mathrm{HHT})$ is a genetic disorder characterized by uncontrolled multisystem angiogenesis with epistaxis, gastrointestinal bleeding, iron-deficiency anemia, and arteriovenous malformations, and is often associated with increased levels of vascular endothelial growth factor (VEGF). Bevacizumab, a VEGF inhibitor, reduces epistaxis, telangiectasias, and irondeficiency anemia. We present the case of a woman with HHT and chronic gastrointestinal bleeding who required iron supplementation and multiple blood transfusions. Bevacizumab resulted in marked symptom improvement and transfusion-independence. Our report describes the dose schedule and calls for a randomized, controlled trial demonstrating the value of bevacizumab therapy.
\end{abstract}

Keywords: Bevacizumab; Dosing; Epistaxis; Hereditary hemorrhagic telangiectasia (HHT)

Corresponding Author:

Narendranath Epperla, MD

Department of Hematology-Oncology

Medical College of Wisconsin

9200 W. Wisconsin Ave.

Milwaukee, WI 53226

Tel: (4I4) 805-4600

Email: nepperla@mcw.edu

Received: October 2, 2013

Revised: December 13, 2013

Accepted: December 17, 2103

doi: $10.3121 / \mathrm{cmr} .2013 .1205$
$\mathrm{H}$ Weber disease, is a rare autosomal dominant, vascular disorder occurring in approximately 1 in 8000 individuals. ${ }^{1,2}$ This multisystem angiogenic disorder is genetically and phenotypically variable; however, the most common presenting symptom is severe and recurrent epistaxis. ${ }^{1,2}$ Other clinical characteristics include mucocutaneous telangiectasias, gastrointestinal bleeding, iron-deficiency anemia, and arteriovenous malformations (AVMs), most commonly in the lung, brain, and liver. ${ }^{1-3}$

Although HHT is often associated with elevated blood levels and tissue expression of vascular endothelial growth factor (VEGF), whether this represents a primary pathophysiologic mechanism or a secondary phenomenon is not clear. ${ }^{2,3}$ Bevacizumab, a VEGF inhibitor, has been shown to reduce epistaxis, telangiectasias, and the need for iron infusions due to stabilized hemoglobin (Hgb). ${ }^{3-10}$ Additionally, there has been marked improvement in symptoms and transfusion requirements. Other reports demonstrated improvement in symptoms and transfusion requirements without an appreciable change in AVMs. ${ }^{4,6}$ DupuisGirod et al showed that bevacizumab administration is associated with improvement in high output cardiac failure, secondary to its effect on liver capillaries and arteriovenous shunting. ${ }^{5,7}$

In the previously reported cases, the dose of bevacizumab varied from $5 \mathrm{mg}$ per kilogram ( $\mathrm{mg} / \mathrm{kg}$ ) body weight ${ }^{1,4-10}$ to $10 \mathrm{mg} / \mathrm{kg}$ body weight ${ }^{3}$ administered every 2 weeks (table 1). The elimination half-life of bevacizumab has been determined to be 18 to 20 days; however, in the study done by Dupuis-Girod et $\mathrm{l}^{5}$ it was 
Table 1: Summary of bevacizumab dose and frequency in HHT.

\begin{tabular}{|c|c|c|}
\hline Bevacizumab Dose & Frequency & Citation \\
\hline $5 \mathrm{mg} / \mathrm{kg}$ & Every 2 weeks & Flieger $\mathrm{D}$ et $\mathrm{a} \mathrm{l}^{8}$ \\
\hline $5 \mathrm{mg} / \mathrm{kg}$ & Every 2 weeks & Mitchell $\mathrm{A}$ et $\mathrm{al}^{7}$ \\
\hline $10 \mathrm{mg} / \mathrm{kg}$ first 2 doses followed by $5 \mathrm{mg} / \mathrm{kg}$ & Every 2 weeks & Bose $\mathrm{P}$ et $\mathrm{al}^{3}$ \\
\hline $5 \mathrm{mg} / \mathrm{kg}$ & Every 2 weeks & Retornaz $\mathrm{F}$ et $\mathrm{al}^{6}$ \\
\hline $5 \mathrm{mg} / \mathrm{kg}$ for first 5 months followed by $7.5 \mathrm{mg} / \mathrm{kg}$ & Every 2 weeks & Oosting S et $\mathrm{al}^{4}$ \\
\hline $5 \mathrm{mg} / \mathrm{kg}$ & Every 2 weeks & Brinkerhoff $\mathrm{BT}$ et $\mathrm{al}^{9}$ \\
\hline $5 \mathrm{mg} / \mathrm{kg}$ & Every 3 weeks & Fodstad $\mathrm{P}$ et $\mathrm{al}^{10}$ \\
\hline $5 \mathrm{mg} / \mathrm{kg}$ & Every 2 weeks & Dupuis-Girod $S$ et al $^{5}$ \\
\hline
\end{tabular}

found to be 21.5 days. The optimal dose and schedule of administration of bevacizumab in the treatment of HHT is unknown.

\section{Case Presentation}

A female patient, aged 57 years, was noted to have microcytic hypochromic anemia in 1990 at age 35, when she presented with hematemesis and a history of melena and epistaxis. An esophagogastroduodenoscopy revealed multiple telangiectasias involving the stomach and duodenum. Her father and three of her siblings had been diagnosed with HHT. A clinical diagnosis of HHT was made. She also had recurrent menorrhagia, and in 1995 underwent a laparoscopic right salpingo-oophorectomy and vaginal hysterectomy. Pathology showed no evidence of malignancy. Prothrombin time, activated partial thromboplastin time, von Willebrand factor, von Willebrand factor antigen, and platelet function testing were all normal. The patient also has asymptomatic pulmonary arteriovenous malformations and one required embolization due to its size.

The patient was on oral iron supplementation and maintained a normal Hgb until age 51 when her $\mathrm{Hgb}$ declined to $<10 \mathrm{~g} /$ $\mathrm{dL}$, associated with an increase in melena and epistaxis. Parenteral iron therapy was initially helpful in maintaining her Hgb levels; however, because of persistent melena and symptomatic anemia, a trial of estrogen supplementation (ethinyl estradiol) was started. She required multiple packed red blood cell (PRBC) transfusions, averaging 2 to 4 units per month to maintain $\mathrm{Hgb}>8.5 \mathrm{~g} / \mathrm{dL}$. Despite iron infusions on a monthly basis, her serum ferritin remained consistently $<30$ $\mathrm{ng} / \mathrm{mL}$. Her estradiol was discontinued in July 2011, since there was no clear clinical benefit.

In September 2011, bevacizumab was initially started at 10 $\mathrm{mg} / \mathrm{kg}$ body weight at every 2 week intervals. Melena resolved within a week, Hgb rose to $14.2 \mathrm{~g} / \mathrm{dL}$ within 4 weeks (figure 1), and serum ferritin increased from $28 \mathrm{ng} / \mathrm{mL}$ to 246 $\mathrm{ng} / \mathrm{mL}$ within 6 weeks, with no further parenteral iron supplementation. She also noted a marked decrease in epistaxis and visible oral mucosal telangiectasias. Once the hematologic picture stabilized, the bevacizumab dose and frequency were gradually reduced (table 2) to lessen the risk of toxicities and cost of therapy with an attempt to determine the minimal effective dose and schedule.

\section{Discussion}

Based on the Curacao criteria developed in 1999, a diagnosis of HHT is considered definitive if at least three of four criteria are present. ${ }^{11}$ The criteria are spontaneous and recurrent epistaxis, telangiectasia, family history, and visceral lesions. Our patient meets all these criteria (four of four).

Genetic linkage studies identified two loci associated with HHT, and the genes involved have been identified: $E N G$ coding for endoglin on chromosome 9q33-q34 (HHT type $1)^{12}$ and $A C R L V 1$ coding for activin receptor-like kinase 1 (ALK1) on chromosome $12 \mathrm{q} 13$ (HHT type 2 ). ${ }^{13}$ Endoglin is a transforming growth factor $\beta$ (TGF- $\beta$ ) binding protein, ${ }^{12}$ while ALK1 is a member of the serine-threonine kinase receptor family. ${ }^{13}$ Each plays a role in the control of blood vessel development and repair. Both endoglin and ALK1 are involved in the TGF- $\beta$ signaling pathway, and a mutation in either gene appears to be sufficient to cause HHT in most patients. $^{2,14}$

Angiogenesis is the formation of new capillary vessels from pre-existing blood vessels. The process can occur in both normal and pathological conditions and is regulated by multifunctional cytokines such as TGF- $\beta 1$ and VEGF. TGF$\beta 1$ plays a role in cellular proliferation, differentiation, and migration, as well as extracellular matrix production and disposition. It has also been shown to stimulate VEGF production. ${ }^{2,3}$ VEGF is produced by a number of different cell types but acts preferentially on vascular endothelium. Its main function is to induce mitotic activity in endothelial cells which initiates capillary blood vessel sprouting. ${ }^{2}$ It has been hypothesized that HHT is a multisystemic, yet localized, angiogenesis disorder caused by the over-expression of VEGF, TGF- $\beta 1$, and ALK1, as well as alterations in other yet to be identified factors. ${ }^{2,14}$ 
Table 2. Dose and frequency of administration of bevacizumab and followup parameters.

\begin{tabular}{|c|c|c|c|c|c|c|}
\hline $\begin{array}{l}\text { Bevacizumab } \\
\text { dose (mg/kg } \\
\text { body wt) }\end{array}$ & $\begin{array}{l}\text { Frequency of } \\
\text { administration }\end{array}$ & $\begin{array}{c}\text { Number of } \\
\text { bevacizumab } \\
\text { doses }\end{array}$ & $\begin{array}{l}\text { Hemoglobin } \\
(\mathrm{g} / \mathrm{dL})\end{array}$ & $\begin{array}{l}\text { Urine for } \\
\text { protein }\end{array}$ & $\begin{array}{l}\text { Blood } \\
\text { pressure } \\
(\mathrm{mmHg})\end{array}$ & $\begin{array}{c}\text { Evidence of } \\
\text { bleed }\end{array}$ \\
\hline 10 & Every 2 wks. & 3 & 14.2 & Negative & $126 / 63$ & None \\
\hline 10 & Every 3 wks. & 3 & 15.1 & Negative & $129 / 68$ & None \\
\hline 10 & Every 4 wks. & 3 & 14.9 & Negative & $141 / 63$ & None \\
\hline 7.5 & Every 4 wks. & 3 & 14.6 & Negative & $129 / 71$ & None \\
\hline 5 & Every 4 wks & 2 & 11.6 & Negative & $123 / 60$ & $\begin{array}{l}\text { Epistaxis, } \\
\text { melena }\end{array}$ \\
\hline 7.5 & Every 4 wks & 1 & 13.1 & Negative & $130 / 72$ & $\begin{array}{l}\text { Mild epistaxis, } \\
\text { melena }\end{array}$ \\
\hline 7.5 & Every 3 wks & 3 & 13.6 & Negative & $134 / 72$ & None \\
\hline
\end{tabular}

Unregulated VEGF expression can lead to uncontrolled angiogenesis, resulting in formation of disorganized, fragile vessels susceptible to rupture. ${ }^{15}$ Thalidomide, with its antiangiogenic properties involving VEGF inhibition, was studied in the treatment of gastrointestinal vascular malformations such as gastric antral vascular ectasia and angiodysplasia, which can lead to gastrointestinal bleeding and iron-deficiency anemia. These vascular lesions share common developmental mechanisms, such as high expression levels of VEGF or other angiogenic factors. Following thalidomide treatment, there was a reduction in gastrointestinal bleeding, and plasma VEGF levels decreased significantly compared to levels before treatment, with the decrease more significant in responders than non-responders. ${ }^{16}$
Bevacizumab is a reasonable agent to consider for the treatment of HHT, based on the molecular mechanisms involved in both angiogenesis and HHT. In our patient, initiation of bevacizumab resulted in rapid resolution of bleeding. The dosing interval of bevacizumab $(10 \mathrm{mg} / \mathrm{kg})$ was gradually increased, starting at 2-week intervals. The dose was then gradually reduced to $5 \mathrm{mg} / \mathrm{kg}$ every 4 weeks. However, after the second dose of bevacizumab at $5 \mathrm{mg} / \mathrm{kg}$, the patient had three episodes of melena along with a drop in her Hgb to $12.1 \mathrm{~g} / \mathrm{dL}$. The administration of $7.5 \mathrm{mg} / \mathrm{kg}$ every 2 to 3 weeks has proven effective in controlling her symptoms without significant adverse effects. This dosing schedule has maintained stable Hgb, obviating the need for further blood transfusions and iron infusions and sustaining the improvement in epistaxis, melena, and telangiectases.

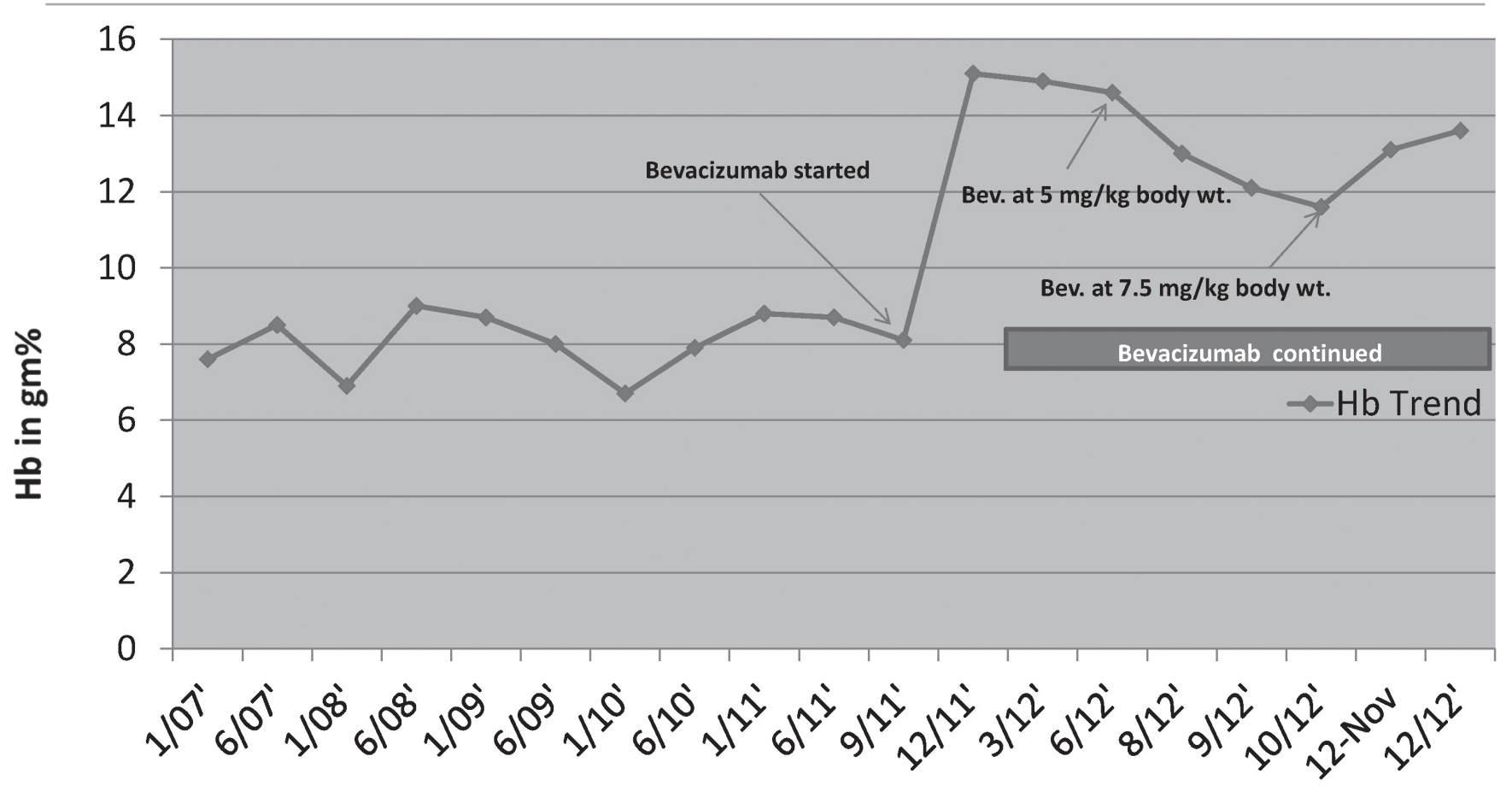

Time in Months

Figure 1: Hemoglobin trend before and after initiation of bevacizumab.

34 Bevacizumab in HHT $\quad$ CM\& $\boldsymbol{R}$ 2015 : 1 (March)




\section{Conclusions}

This report further supports the potential role of bevacizumab in the management of HHT, with a focus on the appropriate dose and schedule. Our observations suggest that bevacizumab at a dose of $7.5 \mathrm{mg} / \mathrm{kg}$ every 2 to 3 weeks is efficacious in controlling bleeding in HHT. We believe that this case adds to a growing body of knowledge demonstrating that there is both a clinical and economic rationale to consider bevacizumab in the management of HHT, and that it may prove superior to conventional therapy in long-term management. A randomized, controlled trial incorporating longer follow-up studies will be necessary to demonstrate the value of this approach.

\section{Acknowledgements}

The authors thank the Marshfield Clinic Research Foundation's Office of Scientific Writing and Publications for assistance in preparing the manuscript.

\section{References}

1. Fleagle JM, Bobba RK, Kardinal CG, Freter CE. Iron deficiency anemia related to hereditary hemorrhagic telangiectasia: response to treatment with bevacizumab. Am J Med Sci 2012;343:249-251.

2. Sadick H, Riedel F, Naim R, Goessler U, Hormann K, Hafner M, Lux A. Patients with hereditary hemorrhagic telangiectasia have increased plasma levels of vascular endothelial growth factor and transforming growth factorbeta1 as well as high ALK1 tissue expression. Haematologica 2005;90:818-928.

3. Bose P, Holter JL, Selby GB. Bevacizumab in hereditary hemorrhagic telangiectasia. N Engl J Med 2009; 360:2143-2144.

4. Oosting S, Nagengast W, de Vries E. More on bevacizumab in hereditary hemorrhagic telangiectasia. N Engl J Med 2009;361:931; author reply 931-932.

5. Dupuis-Girod S, Ginon I, Saurin JC, Marion D, Guillot E, Decullier E, Roux A, Carette MF, Gilbert-Dussardier B, Hatron PY, Lacombe P, Lorcerie B, Rivière S, Corre R, Giraud S, Bailly S, Paintaud G, Ternant D, Valette PJ, Plauchu H, Faure F. Bevacizumab in patients with hereditary hemorrhagic telangiectasia and severe hepatic vascular malformations and high cardiac output. JAMA 2012;307:948-955.

6. Retornaz F, Rinaldi Y, Duvoux C. More on bevacizumab in hereditary hemorrhagic telangiectasia. N Engl J Med 2009;61: 931; author reply 931-932.

7. Mitchell A, Adams LA, MacQuillan G, Tibballs J, vanden Driesen R, Delriviere L. Bevacizumab reverses need for liver transplantion in hereditary hemorrhagic telangiectasia. Liver Transpl 2008;14:210-213.

8. Flieger D, Hainke S. Fischbach W. Dramatic improvement in hereditary hemorrhagic telangiectasia after treatment with the vascular endothelial growth factor (VEGF) antagonist bevacizumab. Ann Hematol 2006;85:631-632.

9. Brinkerhoff BT, Poetker DM, Choong NW. Long-term therapy with bevacizumab in hereditary hemorrhagic telangiectasia. N Engl J Med 2011;364:688-689.

10. Fodstad P, Dheyauldeen S, Rinde M, Bachmann-Harildstad G. Anti-VEGF with 3-week intervals is effective on anemia in a patient with severe hereditary hemorrhagic telangiectasia. Ann Hematol 2011;90:611-612.
11. Shovlin CL, Guttmacher AE, Buscarini E, Faughnan ME, Hyland RH, Westermann CJ, Kjeldsen AD, Plauchu H. Diagnostic criteria for hereditary hemorrhagic telangiectasia (Rendu-Osler-Weber syndrome). Am J Med Genet 2000;91:66-67.

12. McAllister KA, Grogg KM, Johnson DW, Gallione CJ, Baldwin MA, Jackson CE, Helmbold EA, Markel DS, McKinnon WC, Murrell J, et al. Endoglin, a TGF-beta binding protein of endothelial cells, is the gene for hereditary haemorrhagic telangiectasia type 1. Nat Genet 1994; $8: 345-351$.

13. Johnson DW, Berg JN, Baldwin MA, Gallione CJ, Marondel I, Yoon SJ, Stenzel TT, Speer M, Pericak-Vance MA, Diamond A, Guttmacher AE, Jackson CE, Attisano L, Kucherlapati R, Porteous ME, Marchuk DA. Mutations in the activin receptor-like kinase 1 gene in hereditary haemorrhagic telangiectasia type 2. Nat Genet 1996;13:189-195.

14. David L, Mallet C, Mazerbourg S, Feige JJ, Bailly S. Identification of BMP9 and BMP10 as functional activators of the orphan activin receptor-like kinase 1 (ALK1) in endothelial cells. Blood 2007;109:19531961.

15. Lee RJ, Springer ML, Blanco-Bose WE, Shaw R, Ursell PC, Blau HM. VEGF gene delivery to myocardium: deleterious effects of unregulated expression. Circulation 2000; 102:898-901.

16. Ge ZZ, Chen HM, Gao YJ, Liu WZ, Xu CH, Tan HH, Chen HY, Wei W, Fang JY, Xiao SD. Efficacy of thalidomide for refractory gastrointestinal bleeding from vascular malformation. Gastroenterology 2011;141:1629-1637.

\section{Author Affiliations}

Narendranath Epperla, $M D^{* 1}$ and William Hocking $M D$, FACP ${ }^{\dagger}$

"Department of Internal Medicine, Marshfield Clinic, Marshfield, Wisconsin, USA

${ }^{\dagger}$ Department of Hematology-Oncology, Marshfield Clinic, Marshfield, Wisconsin, USA

${ }^{I}$ Current Affiliation: Department of Hematology-Oncology, Medical College of Wisconsin, Milwaukee, Wisconsin, USA 